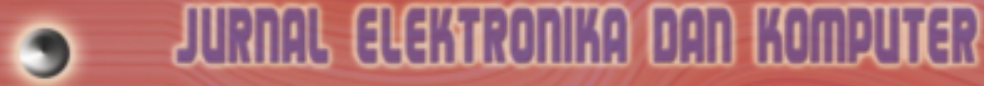

Analisis Pemakaian Sensor Loadcell Dalam Perhitungan Berat Benda Padat dan Cair Agus Wibowo Agus Wibowo

Rancang Bangun Sistem Keamanan Sepeda Motor Menggunakan Rfid dan Personal Identification Number (Pin) Berbasis Mikrokontroler Atmega16

Galang Yudha Murih Raharja, Padjar Setyobudi

Sistem Pencegah Kebakaran Pada Perkebunan Jambu Biji Menggunakan Sensor Suhu Lm35 dan Sms Gateway Berbasis Arduino Uno Kelik Bayu Susatyo

Jurnal ELKOM diterbitkan oleh Sekolah Tinggi Elektronika dan Komputer (STEKOM). Jurnal ELKOM sebagai sarana komunikasi dan penyebarluasan hasil penelitian, pemikiran serta pengabdian pada masyarakat

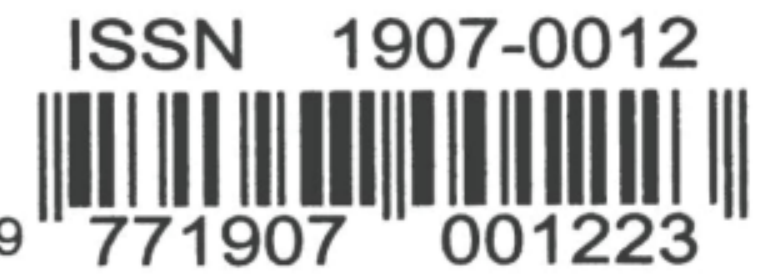

STEKOM

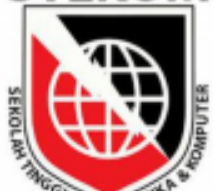
Sekolah Tinggi Elektronika dan Komputer SEMARANG 


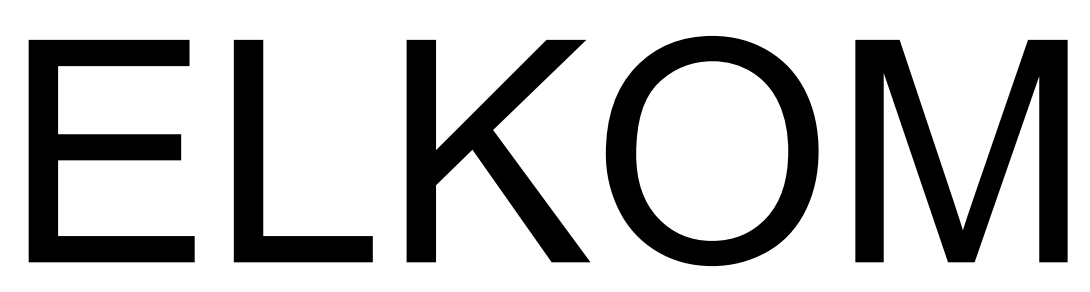

JURNAL ELEKTRONIKA DAN KOMPUTER

Penanggung Jawab :

Ketua Sekolah Tinggi Elektronika \& Komputer

Pemimpin Redaksi :

Sulartopo, S.Pd, M.Kom

Penyunting Pelaksana:

Dr. Ir. Drs. R. Hadi Prayitno, S.E, M.Pd

Dr. Ir. Agus Wibowo, M.Kom, M.Si, M.M

Sarwo Nugroho, S.Kom, M.Kom

Sekretaris Penyunting:

Ir. Paulus Hartanto, M.Kom

Mars Caroline Wibowo, S.T, MT. Tech

Sekretariat :

Dr. Unang Achlison, S.T, M.Kom

Djoko Soerjanto, S.E, M.Kom

Muhammad Sidik, S.Kom, M.Kom

Desain Grafis :

Setiyo Adi Nugroho,S.E, S.Kom

\section{Alamat Redaksi : \\ Pusat Penelitian - Sekolah Tinggi Elektronika \& Komputer (STEKOM) Jl. Majapahit No. 605 Semarang Telp. 024-6710144 E-Mail : \\ elkom@stekom.ac.id}




\section{KATA PENGANTAR}

Puji syukur ke hadirat Tuhan Yang Maha Esa dengan terbitnya Jurnal elektronika dan computer (ELKOM) Edisi Maret 2019, Volume 12 Nomor 1 Tahun 2019 dengan artikel-artikel yang selalu mengikuti perkembangan IImu Pengetahuan dan Teknologi dalam bidang elektronika dan computer. Semua artikel yang dimuat pada Jurnal elektronika dan komputer (ELKOM) ini telah ditelaah oleh Dewan Redaksi yang mempunyai kompetensi di bidang elektronika dan komputer. Pada edisi ini kami menyajikan beberapa topik menarik tentang penerapan elektronika dan komputer yaitu: "Analisis Pemakaian Sensor Loadcell Dalam Perhitungan Berat Benda Padat dan Cair Berbasis Microcontroller", serta "Rancang Bangun Sistem Keamanan Sepeda Motor Menggunakan RFID dan Personal Identification Number (Pin) Berbasis Mikrokontroler Atmega16", selanjutnya "Sistem Pencegah Kebakaran Pada Perkebunan Jambu Biji Menggunakan Sensor Suhu LM35 dan SMS Gateway Berbasis Arduino Uno ", dan "Sistem Pengendalian Suhu Air Nutrisi Hidroponik Nft (Nutrient Film Tehnique) Menggunakan Sensor Suhu Dan Sms Gateway Berbasis Arduino (Studi Kasus Di Siliwangi Indah Hidroponik)". Terima kasih yang mendalam disampaikan kepada penulis makalah yang telah berkontribusi pada penerbitan Jurnal ELKOM edisi kali ini. Dengan rendah hati dan segala hormat, mengundang Dosen dan rekan sejawat peneliti dalam bidang elektronika dan komputer untuk mengirimkan naskah, review, gagasan dan opini untuk disajikan pada Jurnal elektronika dan komputer (ELKOM) ini. Sebagai akhir kata, saran dan kritik terhadap Jurnal elektronika dan komputer

(ELKOM) yang membangun sangat diharapkan. Selamat membaca.

Semarang, Maret 2019 


\section{DAFTAR ISI}

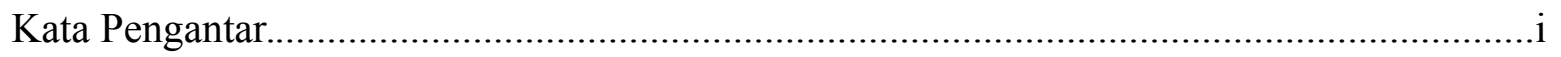

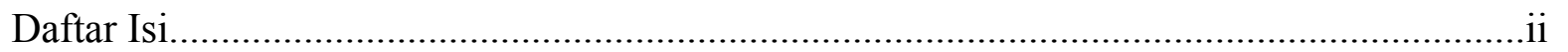

1 Analisis Pemakaian Sensor Loadcell Dalam Perhitungan Berat Benda Padat dan Cair Berbasis Microcontroller, Agus Wibowo...................................... $1-5$

2 Rancang Bangun Sistem Keamanan Sepeda Motor Menggunakan RFID dan Personal Identification Number (Pin) Berbasis Mikrokontroler Atmega16, Galang Yudha Murih Raharja ,Padjar Setyobudi

3 Sistem Pencegah Kebakaran Pada Perkebunan Jambu Biji Menggunakan Sensor Suhu LM35 dan SMS Gateway Berbasis Arduino Uno, Kelik Bayu Susatyo

4 Sistem Pengendalian Suhu Air Nutrisi Hidroponik Nft (Nutrient Film Tehnique) Menggunakan Sensor Suhu Dan Sms Gateway Berbasis Arduino (Studi Kasus Di Siliwangi Indah Hidroponik), Nurul Khabib Allin 


\title{
RANCANG BANGUN SISTEM KEAMANAN SEPEDA MOTOR MENGGUNAKAN RFID DAN PERSONAL IDENTIFICATION NUMBER (PIN) BERBASIS MIKROKONTROLER ATMEGA16
}

\author{
Galang Yudha Murih Raharja1, Padjar Setyobudi 2 \\ Sistem Komputer STEKOM Semarang Email: \\ yudhamilanisti@gmail.com
}

\begin{abstract}
ABSTRAK
Bertambahnya kendaraan bermotor di perkotaan diikuti dengan bertambahnya kasus pencurian sepeda motor dikarenakan kesadaran masyarakat tentang sistem pengamanan sepeda motor masih kurang. Intensitas kejadian pencurian sepeda motor dengan pengungkapannya pun masih jauh perbandingannya. Tindak kriminalitas juga akan ikut meningkat seperti misalnya kasus pencurian kendaraan bermotor khususnya sepeda motor. Kasus pencurian sepeda motor masih sering kali terjadi, hal ini terjadi karena masih kurangnya sistim keamanan yang terdapat di kendaraan bermotor yang hanya menggunakan kunci kontak. keberadaan system pengaman alternative sangat diperlukan karena rata-rata kunci sepeda motor konvensional mudah ditembus oleh pencuri.

Alat pengaman sepeda motor ganda (Doble Smart Lock) yang tersusun dari sebuah RFID dan Personal Identification Number (PIN) dan mikrokontroler ATMega. Sistem ini berfungsi memberikan pengamanan dua tahap. Tahap pertama adalah Mikrpkontroler berupa PIN dan tahap kedua adalah sistem RFID. Bila tahap pertama tembus maka akan memasuki tahap kedua yakni sistem RFID

Hasil berupa alat utama untuk pengeman sepeda motor terdiri dari : Power supplay, RFID Card, RFID Reader, Personal Identification Number (PIN), IC I Mikrokontroler ATMega dan sudah berjalan. Proses pengujian sistem menunjukkan angka 3 pada uji validasi ahli pakar dan angka 3 pada uji coba validasi pihak ahli, Berdasarkan perhitungan di atas, dapat disimpulkan bahwa hasil validasi dari pakar menunjukkan nilai 3 berada diantara $2-3$ yakni tergolong dalam kategori valid. Proses sistem menunjukkan angka 3 pada ujivalidasi ahli pakar dan angka 2,9 pada uji coba validasi pihak user, Berdasarkan perhitungan di atas, dapat disimpulkan bahwa hasil validasi dari user menunjuk kannilai 2,9 berada diantara 2 - 3 yakni tergolong dalam kategori valid.
\end{abstract}

Kata kunci:Sistem Keamanan, RFID, PIN, Mikrokontroler 


\section{Pendahuluan}

Bertambahnya kendaraan bermotor di perkotaan diikuti dengan bertambahnya kasus pencurian sepeda motor dikarenakan kesadaran masyarakat tentang sistem pengamanan sepda motor masih kurang. Intensitas kejadian pencurian sepeda motor dengan pengungkapannya pun masih jauh perbandingannya. Berdasar data Polrestabes Semarang di tiga bulan awal 2015 yakni Januari-Maret, terjadi 186 curanmor di Semarang, baik roda dua maupun empat.

Polrestabes hanya bisa mengungkap 22 kasus. Tren seperti ini hampir tidak berubah dari tahun ke tahun.

Kebutuhan akan
penggunaan teknologi sistem informasi menjadi hal yang tak terelakkan lagi dewasa ini, tak terkecuali di dalam dunia perpustakaan. Penggunaan sistem informasi menjanjikan suatu proses yang lebih efisien daripada proses konvensional. Berbagai macam karya teknologi diciptakan untuk memberikan kemudahan bagi

manusia dalam melakukan aktifitasnya sehari hari. Tidak ketinggalan kemajuan teknologi dibidang elektronika khususnya bidang telekomunikasi. Seiring dengan perkembangan jaman, maka kebutuhan manusia akan

semakin meningkat, tindak kriminalitas juga akan ikut meningkat seperti misalnya kasus pencurian kendaraan bermotor khususnya sepeda motor. Kasus pencurian sepeda motor masih seringkali terjadi, hal ini terjadi karena masih kurangnya sistim keamanan yang terdapat di kendaraan bermotor yang hanya menggunakan kunci kontak. Selain itu juga kurangnya system pengawasan manusia yang masih sering kecolongan. Untuk mengatasi masalah pencurian tersebut salah satunya dengan memberikan system pengaman ganda pada sepeda motor.

Berdasarkan hasil penelitian Riki Astono (2011), menunjukkan bahwa RFID (radio frequency identification) merupakan teknologi baru, salah satunya adalah untuk aplikasi sistem keamanan. Kunci pintu dengan RFID pada dasarnya sama dengan kunci pintu yang lain, biasanya tedapat sensor, unit prosesor dan relay magnetic. Yang membedakan adalah input yang digunakan yaitu menggunakan RFID (radio frequency identification). Berdasarkan latar belakang tersebut penulis membuat alat pengaman sepeda motor ganda (Doble Smart Lock) yang tersusun dari sebuah RFID dan Personal Identification Number (PIN) dan mikrokontroler ATMega. Sistem ini berfungsi memberikan pengamanan dua tahap. Tahap pertama adalah Mikrpkontroler berupa PIN dan tahap kedua adalah sistem RFID. Bila tahap pertama tembus maka akan memasuki tahap kedua yang akan yakni sistem RFID.

\section{Perumusan Masalah}

1. Bagaimana mengidentifikasi sistem keamanan pada sepeda motor?

2. Bagaimana rancang bangun sistem pengaman kendaraan bermotor menggunakan RFID dan Personal Identification Number (PIN) berbasis mikrokontroler AVR ATMega ?

\section{Tujuan Penelitian}

1. Mengidentifikasi kelemahan sistem lama pada sistem kunci sepeda motor konvensional.

2. Mampu mendapatkan suatu sistem pengaman kendaraan bermotor yang dapat dihandalkan.

3. Mengembangkan RFID dan Personal Identification Number (PIN) sebagai alternatif dalam membuat sistem keamanan kendaraan 
bermotor melalui pengujian dari pakar dan pengguna.

\section{Manfaat Penelitian}

Manfaat yang di dapat dari pembuatan skripsi ini adalah :

a. Menambah wawasan dan pengetahuan dalam pembuatan sistem keamanan berbasis Mikrokontroler, RFID dan Personal Identification Number (PIN).

b. Bagi pembaca, dapat didigunakan sebagai acuan terhadap penelitian- penelitian lebih lanjut.

c. Guna pengembangan IPTEK, dapat memberikan suatu karya penelitian yang dapat mendukung dalam pengembangan sistem keamanan berbasis Mikrokontroler, RFID dan Personal Identification Number (PIN).

\section{Tinjauan Pustaka}

1. Pengertian Sistem

Adalah kumpulan dari komponen yang saling berhubungan satu dengan yang lainnya membentuk satu kesatuan untuk mencapai tujuan tertentu. (Jogiyanto, 2009 : 34).

\section{Pengertian keamanan}

Keamanan berasal dari kata pokok "aman" yang berarti : bebas, terlindung dari bahaya, selamat, tidak membahayakan, yakin, dapat dipercaya, dapat diandalkan. Sedangkan keamananmemiliki arti "suasana aman" ketenteraman dan ketenangan (Peter Salim, 2002).

3. Definisi RFID
RFID (Radio Frequency Identification) adalah suatu metode identifikasi secara otomatis (automatic identification system) dengan proses transfer data yang contactless (tidak bersentuhan) antara peralatan yang memuat data dengan pembacanya (pengidentifikasinya), sehingga lebih fleksibel.

4. Mikrokontroler.

Mikrokontroler, sebagai suatu terobosan teknologi mikrokontoler dan mikrokomputer, hadir memenuhi kebutuhan pasar (marketneed) dan teknologi baru. Mikrokontroler adalah sebuah sistem komputer lengkap dalam satu serpih (chip). Mikrokontroler lebih dari sekedar sebuah mikroprosesor karena sudah terdapat atau berisikan ROM (ReadOnly Memory), RAM (Read-Write Memory), beberapa bandar masukan maupun keluaran, dan beberapa peripheral seperti pencacah/pewaktu, ADC (Analog to Digital converter), DAC (Digital to Analog converter) dan serial komunikasi.

5. Personal Identification Number (PIN) Merupakan angka sandi rahasia antara pengguna dan sistem yang dapat digunakan untuk otentikasi pengguna ke sistem. Biasanya,

pengguna diharuskan untuk memberikan identifikasi pengguna umum atau bukti dan PIN rahasia untuk mendapatkan akses ke sistem. Setelah menerima User ID dan PIN, sistem melihat PIN didasarkan pada User ID dan membandingkan PIN pada sistem dengan PIN yang diterima. Pengguna mendapatkan akses hanya bila nomor yang dimasukkan sesuai dengan nomor yang disimpan dalam sistem.

6. Buzzer

Buzzer adalah sebuah komponen elektronika yang berfungsi untuk mengubah getaran listrik menjadi getaran suara. Buzzer terdiri dari kumparan yang terpasang pada diafragma dan kemudian kumparan tersebut dialiri arus sehingga menjadi elektromagnet, kumparan tadi akan tertarik kedalam atau keluar, tergantung dari arah arus dan

polaritas magnetnya, karena kumparan dipasang pada diafragma maka setiap gerakan kumparan akan menggerakkan diafragma secarabolak-baliksehingga 
membuat udara bergetar yang akan menghasilkan suara.

7. Relay

Relay adalah suatu switch elektrik atau saklar yang membuka dan menutupnya dioperasikan oleh suatu magnet listrik.

\section{Basic Compiler AVR}

(BASCOM-AVR)

BASCOM-AVR adalah program Basic Compiler berbasis Windows untuk mikrokontroler keluarga $A V R$.

BASCOM-AVR

merupakan

pemrograman dengan bahasa

tingkat tinggi "BASIC" yang dikembangkan dan diluncurkan oleh MCS Electronics sehingga mudah dimengerti atau diterjemahkan. Dalam program BASCOM-AVR terdapat beberapa kemudahan dalam membuat program software ATmega 16, seperti program simulasi yang sangat berguna untuk melihat simulasi hasil dari program yang telah dibuat sebelum program di-download ke IC atau

mikrokontroler.

\section{Metodologi Penelitian}

Metode penelitian yang digunakan adalah metode penelitian dan pengembangan (Research and Development atau $R \& D)$. Metode penelitianResearchand

Development yang disingkat $R \& D a d a l a h$ metode penelitian yang digunakan untuk menghasilkan produk tertentu, dan menguji

keefektifan produk tersebut.

(Sugiyono, 2012:297).

a. Potensi dan masalah

Potensi merupakan segala sesuatu yang bila didayagunakan akan memiliki nilai tambah. Masalah merupakan penyimpangan antara yang diharapkan dengan yang terjadi dalam hal ini masalah yang terjadi adalah bagaimanakah rancan bangun sistem keamanan sepeda motor menggunakan RFID dan personal identification number (PIN) berbasis Mikrokontroler ATMega16 yang sudah valid di atas di lapangan efektif dan efisien.

b. Pengumpulan Data

Dalam pengumpulan data disini penulis mendapatkan informasi dari observasi, wawancara dan profil bengkel.

c. Desain Produk

Produk yang dihasilkan dalam penelitian Reseach and Development bermacam-macam. Tahap ini akan dimulai dengan

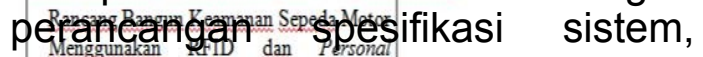
perancangamiperangkat lunak, keras dengingantroler alat bantu perancangan

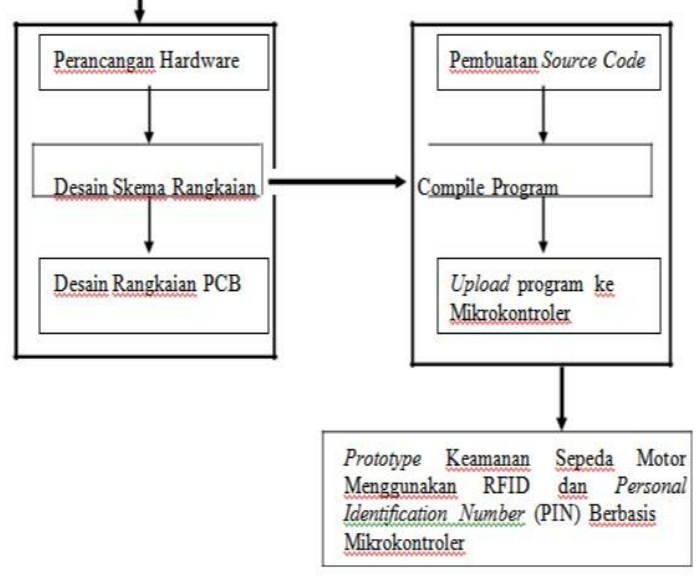

\section{Gambar 1 Blok Diagram Desain}

\section{Sistem}

Hasil Penelitian dan
Pembahasan Berdasarkan
perancangan alat pengaman yang
telah dirancang pada bab
sebelumnya,
berikut ini merupakan implementasi dari Rancang Bangun Sistem Keamanan Sepeda Motor Menggunakan RFID dan Personal Identification Number (PIN) Berbasis Mikrokontroler yang telah dirancang. 1. Skema RangkaiañAlat Utama 
Gambar 2 Skema Rangkaian

Alat Utama

\section{Alat Utama}

Alat utama berupa hardware untuk pengaman sepeda motor terdiri dari :

1) Power supplay

2) RFID Card

3) RFID Reader

4) Personal Identification Number (PIN)

5) IC / Mikrokontroler ATMega

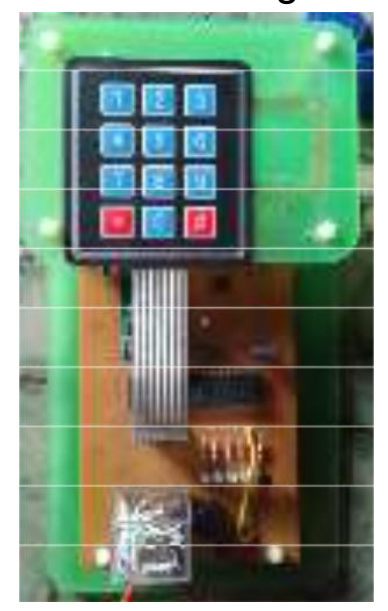

Gambar 3 Alat Utama

3. RFID card dan Reader Merupakan system identifikasi frekuensi radio menggunakan tag atau label yang dipasang pada objek untuk diidentifikasi pada perancangan ini secara khusus modul RFID Reader/Writer, driver untuk membuka sistem awal untuk menuju sistem keamanan kedua yakni PIN.

\section{Personal Identification Number (PIN)}

PIN bisa digunakan setelah system pertama RFID sudah sesuai dengan driver atau tagnya selanjutnya memasukkan nomor PIN untuk pembuka dan pemutus aliran listrik yang masuk kekoil dan buzzer akan menyala ketika kontak pada posisi on dan PIN yang digunakan pada motor tidak sesuai dengan nomor pin atau password yang telah ditentukan

\section{Pembahasan Produk Akhir}

Dari beberapa kajian penelitian yang relevan yang sudah di jelaskan. Penulis telah mengkaji bahwa penelitian yang berjudul "Sistem

Pengaman Sepeda Motor
Menggunakan Fingerprint." dan "Pembuatan Alat Pengaman Sepeda Motor Berbasis Mikrokontroller Atmega8 Dan SMS Gateway" memiliki kesamaan, namun masih ada beberapa kelemahan seperti :

1. Sistem keamanan yang digunakan hanya satu langkah saja

2. Penelitian yang berjudul "Sistem Pengaman Sepeda Motor Menggunakan Fingerprint" alat yang digunakan hanya fingerprint

3. Penelitian yang berjudul "Pembuatan Alat Pengaman Sepeda Motor Berbasis ATMega8 dan SMS Gateway" sangat bergantung pada jaringan kartu GSM yang dipasang dan hanya berlaku satu nomor.

Untuk menyempurnakan hasil kajian penelitian yang sudah ada maka penulis meneliti mengenai rancang bangun sistem keamanan sepeda moto menggunakan RFID dan personal identification number (PIN) berbasis mikrokontroler ATMega16 dengan kelebihan sebagai berikut:

1. Sistem keamanan yang digunakan sudah dua langkah

2. Pengguna sepeda motor bisa menggunakan sebagai pengaman 
tambahan untuk menghindari pencurian sepeda motor

3. Alat dan sistem di dalamnya dapat berjalan dengan baik dengan memasukkan nomor PIN yang benar dan sudah teridentifikasi maka sepeda motor bisa dinyalakan.

Selain itu penulis juga melakukan uji keefektifan dan uji validasi dari ahli program pada sistem keamanan sepeda motor. Dari hasil uji keefektifan dan uji validasi diatas dapat disimpulkan bahwa nilai yang diperoleh dari pakar menunjukkan nilai 3 berada diantara 2

- 3 yakni tergolong dalam kategori valid atau baik. Dari hasil pengujian validator produk dari user atau pengguna dapat disimpulkan bahwa nilai yang diperoleh menunjukkan nilai 3 berada diantara $2-3$ yakni tergolong dalam kategori sangat valid atau baik. Dan pada pengujian efektifitas sistem kerja nilai rata rata yang diperoleh hasil uji efektifitas dari user menunjukkan nilai 3,20 berada diantara 3,10 4,00 yakni tergolong dalam kategori Valid dan Efektif dan bisa digunakan untuk membantu proses sistem keamanan

\section{Kesimpulan dan Saran}

\section{Kesimpulan}

$$
\begin{aligned}
& \text { Berdasarkan hasil analisa, } \\
& \text { maka kesimpulan dari penelitian } \\
& \text { sistem Keamanan Sepeda Motor } \\
& \text { Menggunakan RFID dan Personal } \\
& \text { ldentification Number (PIN) Berbasis } \\
& \text { Mikrokontroler adalah sebagai } \\
& \text { berikut: }
\end{aligned}
$$

1. Kelemahan sistem lama pada sistem kunci sepeda motor konvensional adalah para pencuri sepeda motor sudah semakin melengkapi keahliannya di bidang mekanik kunci motor dan para pengguna sepeda motor umumnya memiliki tingkan keteledoran yang tinggi ketika meninggalkan motornya kunci masih berada di motor sehingga pencuri dapat lebih mudah

2. Hasil berupa alat utama untuk pengeman sepeda motor terdiri dari :Power supplay, RFID Card, RFID Reader, Personal Identification Number (PIN), IC / Mikrokontroler ATMega dan sudah berjalan.

3. Proses pengujian sistem menunjukkan angka 3 pada uji validasi ahli pakar dan angka 3 pada uji coba validasi pihak ahli, Berdasarkan perhitungan di atas, dapat disimpulkan

bahwa hasil validasi dari pakar menunjukkan nilai 3 berada diantara 2 - 3 yakni tergolong dalam kategori valid.Proses sistem menunjukkan angka 3 pada uji validasi ahli pakar dan angka 2,9 pada uji coba validasi pihak user, Berdasarkan perhitungan di atas, dapat disimpulkan bahwa hasil validasi dari user menunjukkan nilai 2,9 berada diantara $2-3$ yakni tergolong dalam kategori valid.

\section{Saran}

Pada sistem Keamanan Sepeda

Motor Menggunakan RFID dan

Personal

Identification Number (PIN)Berbasis

Mikrokontrolerini

dapatdikembangkan lagi yaitu:

a. Pembuatan box bagi peralatan sistem keamanan.

b. Memberi notifikasi peringatan menggunakan buzzer apabila terjadi pengrusakan paksa.

c. Pada penelitian selanjutnya bisa dikembangkan terkoneksi dengan smartphone.

\section{Daftar Pustaka}

Hakim,Lukman. (2009). Sistem Pengaman Kendaraan Bermotor Menggunakan SMS Berbasis Mikrokontroler AVR ATMega8535. Skripsi tidak diterbitkan:UNY Malvino,A.P. (2004). Prinsip-prinsip Elektronika (Terjemahan). Jakarta: Salemba Teknika. Buku asli diterbitkan tahun1999. 
Ramadhan, Ade S. (2015). Rancang

Bangun Sistem Keamanan Rumah

Berbasis Arduino Mega 2560.

(Jurnal Ilmiah) Universitas Dian

Nuswantoro Semarang.

Wardhana, Lingga.(2006).

Belajar Sendiri Mikrokontroler AVR

Seri ATMega8535.

Yogyakarta: Andi Offset.

Hikayana Suki , Ruyung. 2015.

Pengaman Pada Sepeda Motor Untuk Mengurangi Tindak Pencurian, Jurnal Teknik Elektro Universitas Brawijaya

Ihsanto, Eko. 2013. Rancang Bangun Akses Pintu Keluar Masuk Menggunakan PIN Berbasis Mikrokontroller AT89S52, Jurnal Teknologi Elektro, Universitas Mercu Buana.

Rerungan, Juprianto .2014. Sistem Pengaman Pintu Otomatis Menggunakan Radio Frequency Identification (RFID) Tag Card dan Personal Identification Number (PIN) Berbasis Mikrokontroler AVR ATMEGA 128, Jurnal Teknik Elektro, Universitas Tadulako

Oroh, Joyner R. 2014. Rancang Bangun Sistem Keamanan Sepeda Motor Menggunakan Sidik Jari, Jurnal Teknik Elektro dan Komputer, Universitas Sam Ratulangi.

Purnomo, Ragil. 2015. Pembuatan Alat Pengaman Sepeda Motor Berbasis Mikrokontroler ATMega8 dan SMS Gateway, Jurnal Teknik Informatika, AMIK BSI. 